\title{
S-III-6 脳分離体外循環時の脳障害の検討
}

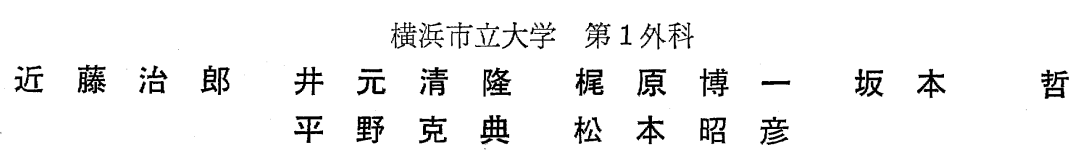

弓部大動脈瘤の手術成績を左右する要因の一つは, 術 中の脳循環の維持である.われわれは, 現在までに弓部 大動脈瘤手術の補助手段として表面冷却超低体温法 ${ }^{1)}$, 表面冷却超低体温法十体外循環併用法, thromboexclusion 法, 脳分離体外循環法などを用いてきた22. 現在は 普遍的な補助手段として脳分離体外循環法を用いてい る. しかし, 本法使用例で脳障害発生例があり, その原 因を含め本法扔よび手術例について検討を加えたので報 告する.

\section{対象と方法}

1984 年 10 月より 1989 年 12 月までの 5 年間に脳分離 体外循環法で手術を行った 20 症例を対象とした. 年齢 は 19 74 歳, 平均 58.5 15.5 歳で男性 13 例, 女性 7 例であった. 真性瘤 12 例, 解離性 8 例であった.

真性瘤症例の年齢は 36 74 歳, 平均 $65.2 \pm 10.1$ 歳, 男女比は $8: 4$ であった. これらのうち 4 例, 33.3 \%が破裂により緊急手術を要した。 また，慢性腎不全で 透析中の 1 例を切迫破裂で緊急手術を行った. 術式は瘤 切除パッチ縫着を 1 例に, 他の 11 例は人工血管にて置 換した. これらのうち 4 例に弓部全置換を行った。

解離性の屯のの年齢は 19 66 歳, 平均 $46.8 \pm 15.8$ 歳之真性瘤例に比べ約 20 歳若年であった. 男女比は $5: 3$ で急性期例 3 例, 非急性期例 5 例であった. 術式 は上行・弓部置換 4 例, Cabrol 手術 1 例, AVR+上 行 - 弓部置換 1 例, 弁付き上行置換 $+\mathrm{CABG} 1$ 例, 上 行置換 1 例であった.

われわれが行っている脳分離体外循環法による手術の 標準的な皮膚切開は図 1 左のでとくである. 弓部 3 分枝 の遮断の場合は，左右腋骷動脈および頸部で左総頸動脈 より送血を行って脳循環を維持した. 術野にカニュレー ションがなく, 手術操作が容易である. 各動脈への送血 は別々のポンプを用いて行った(図1右).

実際には遮断部位により送血部位は異なり, 右腋窩動 脈の夕に送血した部分脳分離体外循環は 3 例, 右腋窩動 脈十左総頸動脈へ灌流を行ったものは 7 例, 右腋窩動
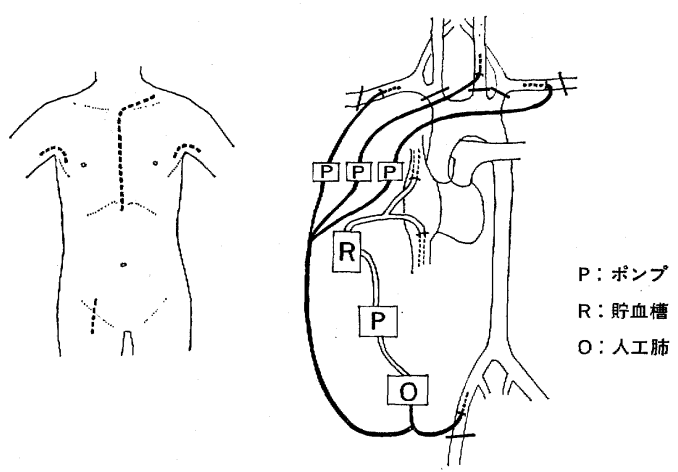

図 1

脈十左総頸動脈十左腋窩動脈へ灌流を行ったものは 10 例であった．左腋窩動脈への灌流は左椎骨動脈および前 脊䯣動脈などへの血流を考慮して最近の症例で行ってい る. 灌流量は食道温 $20^{\circ} \mathrm{C}$ で右腋窩動脈 $200 \sim 250 \mathrm{ml} /$ 分, 左総頸動脈 $150 \sim 200 \mathrm{ml} /$ 分, 左腋窩動脈 $50 \mathrm{ml} /$ 分 とした. 灌流圧は両浅側頭動脈圧で $40 \sim 80 \mathrm{mmHg}$ を 目安とした. 体外循環時間は 137 375 分, 平均 245士 76.8 分, 脳分離体外循環時間は 66 309 分, 平均 150.8 \pm 64.5 分, 大動脈遮断時間は 59 239 分, 平均 $139.9 \pm$ 57.0 分であった。

結果

手術成績は, 術後 1 か月以内の手術死は 4 例, $20 \%$ で あったが，脳障害の 2 例， $10 \%$ が肺炎などで入院死し た. 結局 20 例中 6 例が死亡し, 死亡率 $30 \%$ の結果で あった，てれらを真性瘤解離性にわけてみてみると, 真 性瘤では 12 例中 4 例， $33.3 \%$ が死亡した．破裂例 4 例 中 2 例, $50 \%$ が死亡したのに対 し, 非破裂例 8 例中 2 例， $25 \%$ が死亡した．乙の非破裂例 8 例のうちの 1 例 が切迫破裂で緊急手術を行っており死亡した．緊急手術 を要した 5 例（破裂，切迫破裂）中 3 例， $60 \%$ を救命 しえなかった。

一方, 待期手術 7 例では 1 例を失ったのみであった。 
表 1 手術成績

\begin{tabular}{|c|c|c|c|}
\hline & 例 数 & 死 亡 & 死亡率 (\%) \\
\hline 真 性 瘤 & $12(4)$ & $4(2)$ & 33.3 \\
\hline 解 離 性 & $8[3]$ & $2[2]$ & 25.0 \\
\hline 合 計 & 20 & 6 & 30.0 \\
\hline
\end{tabular}

（）：破裂例，〔〕：急性期例

解離性は 8 例中 2 例， $25 \%$ が死亡したが，死亡例はい ずれも急性期例であった（表 1 ).

死因は真性瘤の 4 例中 2 例が，中大脳動脈領域の塞栓 による脳障害で, 1 例は右冠動脈入口部塞栓による術中 心筋梗塞, 他の 1 例は MOF であった. 解離性の 2 例 はいずれも LOS により死亡した。

術後の合併症は脳障害 3 例, $15 \%$, LOS, MOF, 下肢 筋壊死がおのおの 2 例，10\%に発生した．また胃出血 (多発潰瘍) のため止むなく胃切除を要した 1 例があ り，乙の症例が腹腔よりの感染と思われる縦隔炎を併発 し, 持続洗滌療法を行った. その他反回神経麻瘦を 5 例 で認めた．これらの合併症のうち脳障害と MOF は 全 例と屯真性瘤の症例，とくに，破裂や切迫破裂の緊急手 術例に限定されていた，一方，LOS 亡下肢筋罜死症例 は, 解離性の症例に限られていた。

脳障害発生例は前述したごとく，いずれも真性瘤の破 裂緊急手術例であった．以下簡単に脳障害発生例につい て術中経過を述べ. 1 例目は 71 歳, 男性で術後脳 CT 像で右中大脳動脈領域の梗塞像を示した. この例で は人工心肺回転後すぐ心室細動となり，そのまま灌流冷 却を加えて, 食道温 $29^{\circ} \mathrm{C}$ で大動脈遮断を行い, 続いて 脳分離体外循環を開始した. 乙の心室細動中の大腿動脈 からの逆行送血で塞栓子を飛ばしたものと思われた. 2 例目は 67 歳, 男性で術後脳 $\mathrm{CT}$ 像で左中大脳動脈領域 の梗塞像を示した. この例では, 術中瘤破裂口からの出 血を指でおさえているうちに瘤内指が入り，獬状硬化 物が遊離し脳塞栓を発生したものと考えられた. 3 例目 は65歳, 男性で術後霧視を訴え, 眼底血管に plaque を認め, 塞栓によるあの之診断された。脳 CT 像で後大 脳動脈領域の梗塞像を示した. この症例は人工心肺回転 後, 食道温 $32.4^{\circ} \mathrm{C}$ で心室細動となり大動脈遮断を行っ たのち脳分離体外循環を開始した. 1 例目之同様な原因 で脳梗塞を発生したものと思われた。

\section{考 察}

弓部大動脈瘤に対する外科治療は(超)低体温法と脳分 離体外循環法および心筋保護法の導入により，その成績
は著しく向上した ${ }^{3)}$.しかし，脳分離体外循環法は脳動 脈に個々に灌流するという手技のわずらわしさと至適な 脳灌流圧，灌流量がどのくらいであるのかなどの点でい まだ論議のあるところである．また，術中の脳機能をモ ニタリングする方法も確立されていない．

先に述べたごとく，現在われわれは，手技が容易でい つでもでき，術野を妨げないように送血カニューレを両 腋窩動脈に扦入し, 左総頸動脈も頸部でカニュレーショ ンする方法をとっている. 各灌流量は食道温 $20^{\circ} \mathrm{C}$ で右 腋窩動脈より 200 250 ml/分, 左総頸動脈より 150〜 $200 \mathrm{ml} /$ 分, 左腋窩動脈より $50 \mathrm{ml} /$ 分で, 両浅側頭動脈 圧を $40 \mathrm{mmHg}$ 以上に維持するととにより, 灌流量, 灌 流圧にもとづくと思われる脳障害は経験していない，他 の報告例むほぼ同様である5?.

術中の脳機能モニターとして7 例で血電極, 単極誘導 で脳波を記録し 16 秒間の解析の平均を 1 本のパワース ペクトラム曲線に表示した。 これらの症例はいずれも待 期手術症例で, 明らかな脳虚血を示変化はみられなか った， $22^{\circ} \mathrm{C}$ 以下になると脳波はほとんど平坦化し，乙 れが脳虚血か低体温によるのかの鑑別はできず，復温に より脳波が回復し, 術後の神経学的合併症がなければ, 脳虚血がなかったと retrospective に判断できる程度の モニターと思われた。

その他の問題点は人工心肺によるノイズの混入，二つ の誘導のみのため塞栓などの局所的障害は見逃がされる 可能性があると思われた。 今後さらに有用な脳機能モ二 ターが必要である.

今回の検討例のなかでは脳動脈の灌流圧, 灌流量に伴 う脳障害の発生はなかったが, 真性瘤に扔いて秥状硬化 物などによると思われる脳梗塞を 3 例に経験した. すべ て破裂例であった。破裂例は血液バランスがとりにく く，いずれあ人工心肺回転とともに容易に心室細動之 なった症例で，逆行送血で塞栓子を飛ばしたものと思わ れた。

これらを予防する手段としては，体外循環開始ととも に心拍が十分にあり血圧を維持している時点で脳分離体 外循環を開始するようにして, 弓部 3 分枝に塞栓子が飛 ばない注意を行うとよい，乙の方法で行った 7 例では脳 梗塞は発生していない(図2). また瘤㓦離などの操作 でも慎重に行う必要がある.

しかし, ごく最近, 73 歳男性の動脈硬化性病変の強い

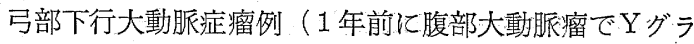
フト置換）に対し，人工心肺回転後食道温 $34^{\circ} \mathrm{C}$ の時点 で脳分離体外循環を開始し, さら飞灌流冷却を続け食道 


\begin{tabular}{|c|c|c|c|c|c|}
\hline & & 直温 $\left({ }^{\circ} \mathrm{C}\right.$ & & & \\
\hline & & 36 & 29 & 25 & 20 \\
\hline I & $\begin{array}{l}\text { 2例 } \\
\text { (0) }\end{array}$ & $\begin{array}{l}\text { T } \\
\text { 体 } \\
\text { 外 } \\
\text { 循 } \\
\text { 環 }\end{array}$ & $\begin{array}{l}\text { 采 } \\
\text { 動 } \\
\text { 脈 } \\
\text { 遮 } \\
\text { 断 }\end{array}$ & $\begin{array}{l}\text { 脸 } \\
\text { 分 } \\
\text { 離 } \\
\text { 体 } \\
\text { 外 } \\
\text { 循 } \\
\text { 環 }\end{array}$ & $\begin{array}{l}\text { 冷 } \\
\text { 却 } \\
\text { 中 } \\
\text { 止 }\end{array}$ \\
\hline & & 36 & 29 & & 20 \\
\hline II & $\begin{array}{r}11 \text { 例 } \\
(3)\end{array}$ & $\begin{array}{c}\text { T } \\
\text { 体 } \\
\text { 外 } \\
\text { 循 } \\
\text { 環 }\end{array}$ & 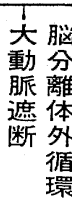 & & $\begin{array}{l}\text { 冷 } \\
\text { 却 } \\
\text { 中 } \\
\text { 止 }\end{array}$ \\
\hline & & 36 & 29 & & 20 \\
\hline III & $\begin{array}{c}7 \text { 例 } \\
(0)\end{array}$ & $\begin{array}{l}\text { 体脸 } \\
\text { 外分 } \\
\text { 循離 } \\
\text { 䍗 体 } \\
\text { 循 } \\
\text { 環 }\end{array}$ & $\begin{array}{l}\text { 動 } \\
\text { 脈 } \\
\text { 遮 } \\
\text { 断 }\end{array}$ & & $\begin{array}{l}\text { 冷 } \\
\text { 却 } \\
\text { 中 } \\
\text { 止 }\end{array}$ \\
\hline
\end{tabular}

図 2 脳分離体外循環

温 $31^{\circ} \mathrm{C}$ で心室細動になった後に大動脈遮断を行った。 弓部下行大動脈瘤を切除し人工血管置換を行い，心蘇生 を試みたが心蘇生ができない症例を経験した。上行大動 脈を切開してみると，右冠動脈口に粥状硬化物が荻頓す る形となっていた，脳動脈に限らず重要動脈への粘状硬 化物による塞栓には十分な注意を払う必要があるすのと
思われた.

耐術例 14 例につき術式之遠隔成績を検討したが， 6 か月〜 5 年 2 か月，平均 2 年 4 か月の観察期間では遠隔 死を認めなかった。遠隔期において 1 例が腹部大動脈瘤 破裂のため手術が行われた。また1例で胸骨骨髄のため 胸骨および肋乾骨の切除を要した，術式による合併症も 認めていない，後遺症としては視力障害（後大脳動脈梗 塞栓） 1 例，右下肢歩行障害（右下肢筋壊死）1.例，嗄 声 2 例をのこしたが、いずれも社会生活に復州した。

\section{まとめ}

1）脳分離体外循環による 20 症例を検討した。

2) 手術死亡 4 例 $(20 \%)$, 病院死 2 例 $(10 \%)$ であっ た.

3）術後脳障害が 3 例（15\%）に発生した.うち2例 が病院死した。いずれも脸塞栓で, 灌流圧, 灌流量が原 因之思われる脳障害ではなかった。脳塞栓発生例はいず れも破裂真性瘤例であった。

4) 脳塞栓発生を予防するには，脸分離体外循環を心 拍が十分にあり血圧のある時期に開始するのがよいと思 われた。

文 献 1) 松本昭彦ほか：胸部外科 31：938，1978。2) 近 藤治郎ほか：日胸外会誌 34:664, 1986. 3) Cooley, D. A. et al. : Ann. Thorac. Surg. $32: 260,1981.4)$ 川島康生ほ加: 動脈瘤の治療, 補助手段一分離体外循環一, 外科 Mook 50 ,

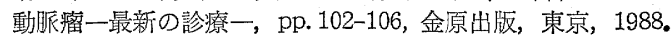

\title{
S-III-7 落差式脳分離体外循環による弓部大動脈瘤の治療
}

\author{
埼玉医科大学 第 1 外科 \\ 安達秀雄横手祐二許俊鋭木村壮介 \\ 尾 本良 三
}

弓部大動脈瘤の手術治療に際しては，虚血に最む弱い 臓器とされる脳の保護を必要とするため, 本邦における 手術成績は必ずしも満足できるあのではなかった。

しかし, 近年体外循環技術の発展, 縫合材料の進歩, 術前術後管理の進歩さらに手術手技の向上などが相まっ て手術成績の飛躍的向上がみられつつある.とくに米国 では Cooley ${ }^{1\rangle}$ や Crawford ${ }^{2)}$ らの100例在越すシリー ズの成績が報告され，いずれも死亡率は 10～15\% と低
率となってきている. 本邦においても川島3》 や中島" が全体の症例数はやや少ないながら, 死亡率は 10２0 \%と良好な手術成績を報告している. 弓部大動脈瘤手 術に扣いては心筋保護ととすに脳保護が重要であり, Cooleyと Crawford はいずれも超低体温下循環遮断法 を用いており，また川島，中島らは低体温下脳分離体外 循環法を用いている.

当科に打いても従来ポンプによる脸分離体外循環法お 